\title{
Cue-overload theory and the method of interpolated attributes
}

\author{
MICHAEL J. WATKINS and OLGA C. WATKINS \\ University of Toronto, Toronto, Ontario, Canada M5S $1 A 1$
}

\begin{abstract}
A theory is outlined in which recall is assumed to be mediated by retrieval cues that are subject to overload. A simple method is described for exploring the nature of these retrieval cues, and it is illustrated with 12 small experiments. The method is compared with Wickens' release from proactive inhibition procedure.
\end{abstract}

Much of the current theoretical speculation about human memory is specific to some particular paradigm. There have, however, been a few recent attempts to integrate the findings of different paradigms within a general theoretical framework. One example is Craik and Lockhart's (1972) levels of processing approach. The present paper is concerned with another possible theoretical framework, one we call cue-overload theory (Watkins \& Watkins, 1975). Whereas Craik and Lockhart's analysis focuses on how events are encoded into memory, cue-overload theory deals with how events are retrieved from memory.

In essence, cue-overload theory says that the recall of an event is mediated by retrieval cues and that these cues are subject to overload. Thus the recall of a given eventsuch as the presentation of a verbal item-declines as more and more other events come to share its retrieval cue. The phenomena that can be interpreted within this framework are many and varied, as is illustrated by the following examples. (a) Negative transfer and retroactive inhibition in the $\mathrm{AB}-\mathrm{AC}$ paired-associate paradigm: Here a nominal retrieval cue (A) is shared by two responses (B and C). (b) The build-up of, and release from, proactive inhibition: The decline in recall over successive trials of the Brown-Peterson paradigm when items are drawn from the same category can be attributed to the category retrieval cue becoming less effective as it subsumes more items, and the increase in recall when the category is changed can be seen as reflecting the use of a fresh retrieval cue (Watkins \& Watkins, 1975). (c) The list length effect-the decrease in probability of recalling a given list item as list length increases: In this case we can assume that recall is mediated, at least partly, by a cue corresponding to "list" (or "last list") and that this cue becomes overloaded as list length is increased. (d) The recency effect in free recall: It seems that type of item and conditions of presentation have relatively little effect on recall of recency items (see, e.g., Glanzer, 1972), a fact which suggests that recall of these items is mediated

This research was supported by the National Research Council of Canada Grant A8632 to Endel Tulving. by a distinct "primary memory" cue (cf. Tulving, 1968; Watkins, 1974). (e) The effect of list structure on free recall: The higher level of recall observed when list items fall into distinct categories can be interpreted by assuming that recall can be mediated by cues that correspond to the categories. (f) The inhibition effect of part-list cueing: Slamecka's (1968) finding that the re-presentation of some proportion of the list items inhibits free recall of the remaining items can be explained by assuming that the retrieval cues-whether they correspond to the entire list or to clusters or categories within the list-become less efficient through contact with the re-presented items. This view is perhaps rendered more plausible by the finding of comparable inhibition effects when extralist items are presented at recall (Watkins, 1975).

At its current level of development, cue-overload theory serves as a loose framework within which diverse findings are interpreted from a common viewpoint. Whether the theory can profitably be stated more formally remains an open question. To constrain any such theoretical development, we need a good deal more information on the efficiency of various classes of retrieval cues. It is the purpose of this paper to describe a very simple method for obtaining such information and to illustrate it with 12 small experiments.

\section{METHOD}

The method we use for exploring the nature of functional retrieval cues we call the method of interpolated attributes. It can be thought of as a stripped-down version of the extralist cueing procedure (Watkins, 1975), while at the same time it conforms to the classical retroactive inhibition paradigm.

\section{Procedure}

The subject sees a memory list of six items displayed as a set for $6 \mathrm{sec}$, and immediately afterwards sees a second interpolated list of six items. His task is to study the memory list, copy the items of the interpolated list immediately they appear, and then try to recall the items of the memory list. The items are presented by slide projector, and the subject writes his recall responses at his own rate using a separate sheet for each trial. The subject is told that he is free to recall the items in any order he pleases, though typically he elects to recall them in their 
Table 1

Summary of Design and Results of the 12 Experiments

\begin{tabular}{|c|c|c|c|c|c|c|c|c|c|c|}
\hline \multicolumn{6}{|c|}{ Methodological Details } & \multicolumn{5}{|c|}{ Results } \\
\hline \multirow{3}{*}{$\begin{array}{l}\text { Experi- } \\
\text { ment } \\
\text { No. }\end{array}$} & \multirow{3}{*}{$\begin{array}{l}\text { Description of } \\
\text { Attribute } \\
\text { Manipulation }\end{array}$} & \multirow{3}{*}{$\begin{array}{l}\text { Cate- } \\
\text { gories } \\
\text { Used }\end{array}$} & \multicolumn{3}{|c|}{ Number of } & & & & & \multirow{3}{*}{$\begin{array}{c}\text { Statistical } \\
\text { Analysis } \\
\text { of D - S }\end{array}$} \\
\hline & & & $\begin{array}{l}\text { Trials/ } \\
\text { Sub- } \\
\text { ject in }\end{array}$ & $\begin{array}{l}\text { Sub- } \\
\text { jects }\end{array}$ & $\begin{array}{l}\text { Obser- } \\
\text { vations/ } \\
\text { Condi- }\end{array}$ & \multicolumn{2}{|c|}{$\begin{array}{l}\text { Mean Recall } \\
\text { (Percentage) }\end{array}$} & \multicolumn{2}{|c|}{$\begin{array}{c}\text { Effect of } \\
\text { Attribute Change } \\
\text { (Percentage) }\end{array}$} & \\
\hline & & & $\begin{array}{l}\text { Condi- } \\
\text { tion }\end{array}$ & & & $S$ & D & $D-S$ & $(D-S) / S$ & \\
\hline 1 & $\begin{array}{l}\text { Acoustic similarity: } \\
\text { Rhyme categories }\end{array}$ & 8 & 4 & 32 & 768 & 41.0 & 56.4 & 15.4 & 37.6 & $t(31)=5.52^{*}$ \\
\hline \multirow[t]{2}{*}{$\begin{array}{l}2 \\
3 \\
4 \\
5 \\
6 \\
7\end{array}$} & $\begin{array}{l}\text { Taxonomic categories } \\
\text { Letters/digits } \\
\text { Place of articulation } \\
\text { Words/Numbers } \\
\text { Initial three letters } \\
\text { Semantic differential }\end{array}$ & $\begin{array}{r}8 \\
2 \\
2 \\
2 \\
10\end{array}$ & $\begin{array}{l}4 \\
6 \\
4 \\
4 \\
5\end{array}$ & $\begin{array}{l}32 \\
24 \\
32 \\
56 \\
24\end{array}$ & $\begin{array}{r}768 \\
864 \\
768 \\
1344 \\
720\end{array}$ & $\begin{array}{l}58.5 \\
68.5 \\
45.0 \\
32.2 \\
44.6\end{array}$ & $\begin{array}{l}68.6 \\
77.3 \\
53.0 \\
40.0 \\
46.1\end{array}$ & $\begin{array}{r}10.1 \\
8.8 \\
8.0 \\
7.8 \\
1.5\end{array}$ & $\begin{array}{r}17.3 \\
12.8 \\
17.8 \\
24.2 \\
3.4\end{array}$ & $\begin{array}{l}\mathrm{t}(31)=3.83^{*} \\
\mathrm{t}(23)=3.51^{*} \\
\mathrm{t}(31)=3.49^{*} \\
\mathrm{t}(55)=3.69^{*} \\
\mathrm{t}(23)<1\end{array}$ \\
\hline & $\begin{array}{l}\text { (a) Evaluation } \\
\text { (b) Activity } \\
\text { (c) Potency }\end{array}$ & $\begin{array}{l}2 \\
2 \\
2\end{array}$ & $\begin{array}{l}4 \\
4 \\
4\end{array}$ & $\begin{array}{l}24 \\
24 \\
24\end{array}$ & $\begin{array}{l}576 \\
576 \\
576\end{array}$ & $\begin{array}{l}60.9 \\
57.1 \\
60.6\end{array}$ & $\begin{array}{l}64.8 \\
58.5 \\
59.5\end{array}$ & $\begin{array}{r}3.9 \\
1.4 \\
-1.1\end{array}$ & $\begin{array}{r}6.4 \\
2.5 \\
-1.8\end{array}$ & $\begin{array}{l}t(23)=1.18 \\
t(23)<1 \\
\text { N.A. }\end{array}$ \\
\hline \multirow{2}{*}{$\begin{array}{l}8 \\
9\end{array}$} & $\begin{array}{l}\text { Combined } \\
\text { Frequency of usage }\end{array}$ & $\begin{array}{l}6 \\
2\end{array}$ & $\begin{array}{r}12 \\
4\end{array}$ & $\begin{array}{l}24 \\
24\end{array}$ & $\begin{array}{r}1728 \\
576\end{array}$ & $\begin{array}{l}59.5 \\
42.1\end{array}$ & $\begin{array}{l}60.9 \\
43.4\end{array}$ & $\begin{array}{l}1.4 \\
1.3\end{array}$ & $\begin{array}{l}2.4 \\
3.1\end{array}$ & $\begin{array}{l}\mathrm{t}(23)<1 \\
\mathrm{t}(23)<1\end{array}$ \\
\hline & $\begin{array}{l}\text { Part of speech: } \\
\text { Noun/verb/adjective }\end{array}$ & 3 & 6 & 32 & 1152 & 45.1 & 46.4 & 1.3 & 2.9 & $\mathrm{t}(31)<1$ \\
\hline \multirow{2}{*}{$\begin{array}{l}10 \\
11\end{array}$} & Sex connotation & 2 & 2 & 32 & 384 & 61.5 & 60.7 & -.8 & -1.3 & N.A. \\
\hline & $\begin{array}{l}\text { One-syllable/two- } \\
\text { syllable words }\end{array}$ & 2 & 2 & 32 & 384 & 41.9 & 40.6 & -1.3 & -3.1 & N.A. \\
\hline 12 & Sense impression & 8 & 4 & 40 & 960 & 58.6 & 56.3 & -2.3 & -3.9 & N.A. \\
\hline
\end{tabular}

Note $-S=$ same condition, $D=$ different condition

${ }^{*} p<.001$

presentation order. There are two conditions. In the same condition the two lists of items are sampled from the same population; in the different condition the two lists are sampled from populations that differ in some clearly defined way.

\section{Subjects and Design}

All subjects were University of Toronto undergraduates who were paid for participating. Some were tested individually, others in groups of up to six persons. In some cases, two or three experiments were conducted in the same session, so that some subjects took part in more than one experiment. Within each experiment several six-item lists were formed for each included category. The number of categories varied between experiments. For instance, Experiment 3 used only two categories (letters and digits), whereas Experiment 2 used eight (body parts, musical instruments, countries, occupations, fruits, sports, four-legged animals, and means of transport). Between-subject balancing insured that each list occurred equally often in the same and different conditions, as well as equally often as a memory list and as an interpolated list. Thus any difference in performance between conditions could not be the result of a selection effect in either the memory or the interpolated lists.

Within each experiment the order of conditions of successive trials was assigned at random. With this randomization we avoided confounding possible effects of proactive inhibition with condition. We should note, however, that category-specific proactive effects were probably minimal, for care was taken to interpolate other activity-either from other experiments in the present series or from experiments of a different sort-between successive trials.

\section{Rationale}

From cue-overload theory we assume that recall in the different condition will exceed that in the same condition to the extent that the attribute distinguishing the two populations corresponds to a functional retrieval cue. Thus we gain information about functional retrieval cues by comparing recall for the same and different conditions using various types of attribute shifts.

\section{INDIVIDUAL EXPERIMENTS}

The details of the individual experiments are shown in Table 1. The experiments are ordered according to the observed effectiveness of the attribute shift (as measured by the absolute advantage of the different over the same condition). The critical attributes of some of the experiments need to be clarified, and this is perhaps most readily achieved by way of example. Table 2 shows for the less explicit attributes examples of two lists drawn from different categories.

The principal results are included in Table 1. Two measures of the effectiveness of the attribute shift are provided. The first is given simply by the absolute advantage of the different over the same condition, whereas the second expresses this advantage as a fraction of performance in the same condition. Dependent $t$ tests were performed for the significance of the benefit of the attribute shift, with subjects as the random variable.

\section{DISCUSSION}

It would seem that our method is indeed useful for exploring the nature of functional retrieval cues insofar as some attribute shifts are associated with increased recall performance, while 
Table 2

Examples of Lists from Different Categories for Less Explicit Attributes

\begin{tabular}{cl}
\hline Experiment No. & Examples of Lists Used \\
\hline 1 & SNAKE FLAKE BAKE QUAKE STEAK WAKE \\
& SOUL FOAL TOLL WHOLE BOWL POLE \\
& EARL ORAL ROLLER RAIL LIRA LAUREL \\
& POET TIPTOE PEAT TAPE POTATO POUT \\
& COMPARE COMMENCE COMMAND COMPLAIN COMPOSE COMBINE \\
& BANDAGE BANQUET BANNER BANKER BANGLE BANISH \\
& CIGAR BARITONE PRIEST STALLION FOOTBALL MUSTACHE \\
& PETTICOAT QUEEN PERFUME DOE PURSE SISTER \\
& WHEEL BALLOON DOME SAUCER GLOBE DOUGHNUT \\
& SEWER GASOLINE SKUNK MANURE AMMONIA GARBAGE \\
\hline
\end{tabular}

others are not. In particular, it seems that the following nominal distinctions correspond in varying degrees to functional retrieval cues: (a) rhyme classes, (b) taxonomic categories, (c) letters and digits, (d) certain categories based on place of articulation, and (e) words and numbers. We should not, however, equate these distinctions with functional cues, since there is little doubt that in an absolute sense (i.e., relative to the advantage that would be observed with no distractor task) the advantage of switching categories for the distractor task is rather modest. On the other hand, the findings do provide some basic information about the nature of functional cues. It is possible that, on the basis of such findings, cue-overload theory could be given a more rigorous formulation.

The method of interpolated attributes is, of course, not new. It is merely a version of the traditional method of retroaction. On the other hand, it is a version that has fallen into disuse. This neglect is surprising in view of the recent interest in the "code" of the memory trace, especially in short-term memory. Those studies that have been reported have typically dealt with acoustic similarity (Dale, 1964; Dale \& Gregory, 1966; Wickelgren, 1965), and their results are essentially compatible with those of our Experiment 1. The Dale and Gregory (1966) study, however, also varied semantic similarity and found a slight recall advantage when semantic category was shifted. Finally, Sanders and Schroots (1969) have extended the retroaction paradigm to mixed verbal and nonverbal events; research of this sort holds the promise that cue-overload theory may prove useful in integrating some aspects of verbal and nonverbal cognitive abilities.

The method of interpolated attributes clearly relates to Wickens' (1970) build-up of proactive inhibition procedure. Both use an attribute shift technique, and both are used for the express purpose of exploring the attributes of memory for verbal events. One question we might ask is whether the two methods give comparable results. Although a comparison of the present findings and those from studies using Wickens' procedure suggest some discrepancies (viz. frequency of usage, semantic differential, sex connotation, sense impression, and perhaps place of articulation), it is perhaps too early to give a definite answer. A second basic question concerns the relative merits of the two methods, both from a practical and a theoretical viewpoint. From a practical viewpoint, the method of interpolated attributes would seem to be the more efficient. It more readily lends itself to group testing, and the procedure is simpler and briefer. A certain inefficiency in Wickens' method no doubt reflects its origin in a controversy that has little if anything to do with its present application; it seems likely that much of the procedural detail is superfluous and serves merely to add noise. From a theoretical viewpoint-or at least from the viewpoint of cue-overload theory-the method of interpolated attributes again seems preferable. The advantage stems from the fact that the experimental manipulation occurs after presenta- tion of the memory list. It follows that, provided the two conditions are given in unpredictable order, the encoding of the memory list will be equivalent for the two conditions. With Wickens' method, on the other hand, the interfering items are presented before the critical items. This means that a difference in release between the shift and nonshift conditions could arise from a difference in the efficiency of either the encoding or the retrieval process. Although we have argued elsewhere (Watkins \& Watkins, 1975) that the difference is probably best thought of as one of retrieval, this view is by no means universally accepted. Thus, theoretical as well as practical considerations would seem to favor the method of interpolated attributes.

\section{REFERENCES}

Craik, F. I. M., \& Lockhart, R. S. Levels of processing: A framework for memory research. Journal of Verbal Learning and Verbal Behavior, 1972, 11, 761-784.

DALE, H. C. A. Retroactive interference in short-term memory. Nature, 1964, 203, 1408.

DALE, H. C. A., \& GREgory, M. Evidence of semantic coding in short-term memory. Psychonomic Science, 1966, 5, 75-76.

Glanzer, M. Storage mechanisms in recall. In G. H. Bower (Ed.), The psychology of learning and motivation: Advances in research and theory (Vol. 5). New York: Academic Press, 1972.

Sanders, A. F., \& Schroots, J. J. F. Cognitive categories and memory span: III. Effects of similarity on recall. Quarterly Journal of Experimental Psychology, 1969. 21. 21-28.

Slamecka, N. J. An examination of trace storage in free recall. Journal of Experimental Psychology, 1968, 76, 504-513.

Tulving, E. Theoretical issues in free recall. In T. R. Dixon \& D. L. Horton (Eds.), Verbal learning and general behavior theory. Englewood Cliffs, N.J: Prentice Hall. 1968.

Watkins, M. J. Concept and measurement of primary memory. Psychological Bulletin, 1974, 81, 695-711.

W ATKINs, M. J. Inhibition in recall with extralist "cues." Journal of Verbal Learning and Verbal Behavior, 1975, 14, 294-303.

Watkins, M. J. Inhibition in recall with extralist "cues." Journal of Verbal Learning and Verbal Behavior, 1975, 14. 294-303.

Watkins, O. C., \& Watkins, M. J. Buildup of proactive inhibition as a cue-overload effect. Journal of Experimental Psychology: Human Learning and Memory, 1975, 1, 442-452.

Wickelgren, W. A. Acoustic similarity and retroactive interference in short-term memory. Journal of Verbal Learning and Verbal Behavior, 1965, 4, 53-61.

WiCKENS, D. D. Encoding categories of words: An empirical approach to meaning. Psychological Review, 1970, 77, 1-15.

(Received for publication November 12, 1975.) 